\title{
Hydrocarbon accumulation principles in troughs within faulted depressions and their significance in exploration
}

\author{
Zhao Xianzheng*, Jin Fengming, Wang Quan and Lu Xuejun \\ Huabei Oilfield Company, PetroChina, Hebei 062552, China \\ (C) China University of Petroleum (Beijing) and Springer-Verlag Berlin Heidelberg 2011
}

\begin{abstract}
Previously, troughs in continental faulted depressions were usually considered as a zone of hydrocarbon generation and expulsion rather than a zone for hydrocarbon accumulation. If they were confirmed to be the source kitchen, the possibility that they could constitute potential plays would be overlooked in the subsequent exploration program. Based on the hydrocarbon exploration practice of the Jizhong Depression and the Erlian Basin in the past several years, this paper discusses a new understanding that reservoir distribution is controlled by multiple factors and lithological accumulations are more likely to form in trough areas. It further documents the three main factors controlling the formation of large lithological hydrocarbon accumulations in trough areas. The paper also discusses the new concept that structural and lithological accumulations not only co-exist but also complement each other. We propose that fan-delta fronts on inverted steep slopes in troughs, delta fronts and sublacustrine fans on gentle slopes, channel sands along toes of fault scarps are favorable locations for discovery of new oil accumulations. The application of this concept has led to the discovery of several hundreds of million tonnes of oil in place in trough areas in the Jizhong Depression and the Erlian Basin.
\end{abstract}

Key words: Sand distribution, multiple controlling factors, preferential hydrocarbon accumulation, accumulation in troughs, accumulation model, exploration method

\section{Introduction}

The theory of "oil generated in younger formations but reservoired in older formations" for buried hill plays, and the theory of "multiple structural belts for hydrocarbon accumulation" (Li, 1994; Hu and Niu, 2001) have guided oil and gas exploration practice in the faulted depressions in east China. This has led to the discovery of a great number of giant and medium sized oil and gas fields which are mainly distributed in structural high belts. After 40 years' exploration, with an increasing exploration maturity, exploration has been focusing on non-structural traps. New discoveries in structural highs are becoming fewer and fewer (Zhao et al, 2005b). Based on incomplete statistics, the total proven oil in place in the faulted basins in east China is about $10.9 \times 10^{9} \mathrm{t}$, while the undiscovered oil resource in place is estimated to be up to $29.1 \times 10^{9} \mathrm{t}$, which is largely distributed in trough areas. As a result, the troughs have become the current exploration focus.

The trough area refers to the middle-lower segments of slopes and deep sags in a depression (Fig. 1), characterized by weak structural activities and underdevelopment of structural

*Corresponding author. email: xzzhao@petrochina.com.cn Received April 13, 2010 traps. However, studies have indicated that stratigraphic traps are more likely to form in troughs (Liu et al, 2006; Zhao et al, 2008a). Since the start of the 21st century, exploration in trough areas has been intensified. As a result, several hundreds of million tonnes of oil in place have been found in troughs in the Jizhong Depression and the Erlian Basin (Du et al, 2003; Jin et al, 2004a; 2004b; 2008; Zhao et al, 2007b). A great deal of research and practice has showed that trough areas in faulted depressions possess special petroleum accumulation attributes. That is, in trough areas, reservoir sand distribution is controlled by multiple factors. Lithological accumulations are more likely to form and reservoir forming areas are controlled by the main trough area. Three factors control the formation of large lithological hydrocarbon accumulations and structural and lithological accumulations not only co-exist but also complement each other.

Based on the above principles, it is known that fan-delta fronts on the inverted steep slope in a trough, delta fronts and sublacustrine fans on the gentle slope, and channel sands along toes of fault scarps are favorable locations for hydrocarbon to accumulate in stratigraphic traps.

\section{Multiple controlling factors for sand distribution in trough areas}

Because of weak structural activities and 


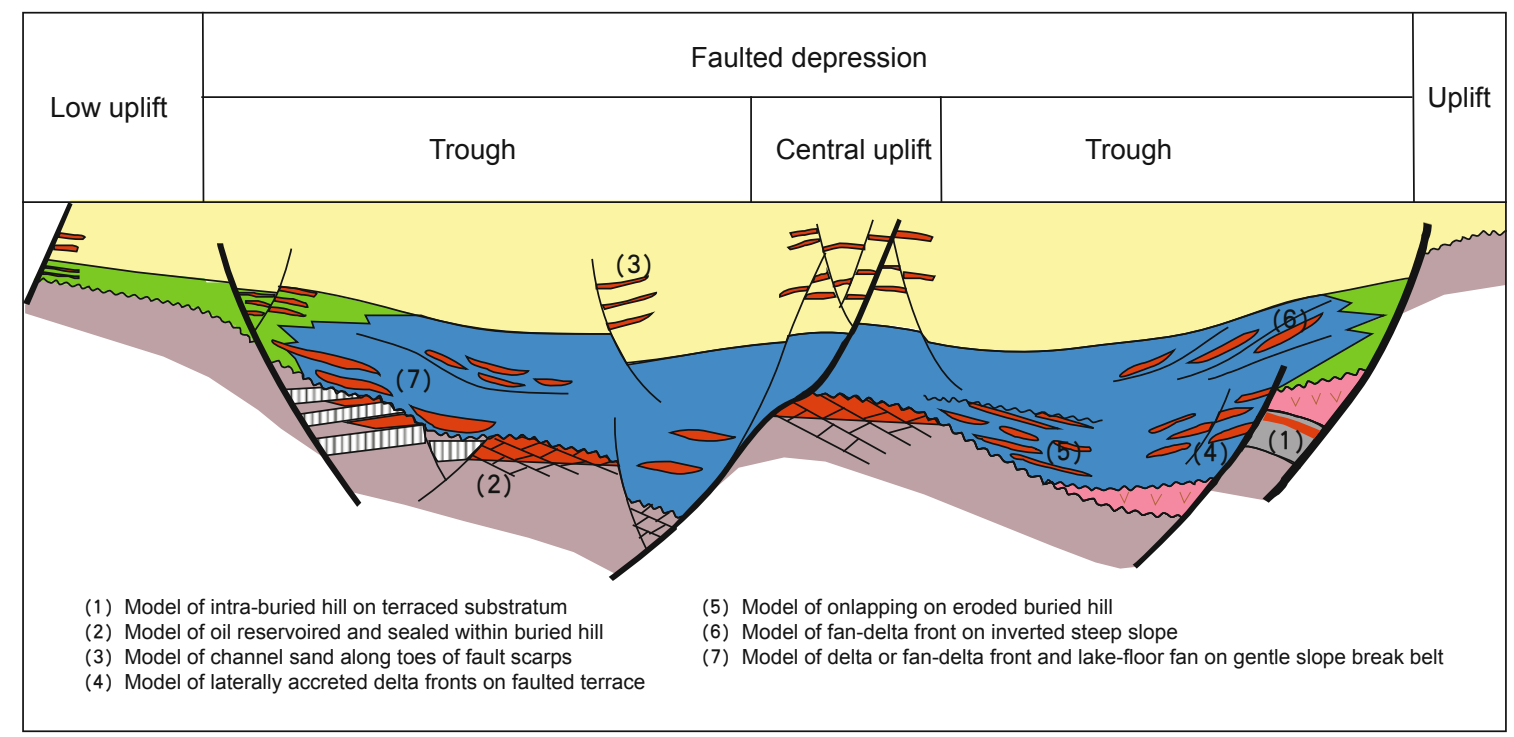

Fig. 1 Trough structures and hydrocarbon accumulation patterns

underdevelopment of structural traps in trough areas, the development of sandbodies is vital for oil accumulation. Studies have shown that the formation and distribution of sandbodies are dominated by multiple factors, which include the configuration patterns of troughs, the combination styles of boundary faults, the type of slope break belt, the pattern of systems tracts and the type of sedimentary facies (Zhao et al, 2007a).

\subsection{Style of boundary faults controlling main sediment inputs}

The occurrence and combination styles of boundary faults control the development of the patterns of palaeo-rivers. Inter-mountain rivers generally flow into the lake basin along the local lows from eroded boundary faults on the steep slopes, forming fan-deltas or proximal sublacustrine fans. Connecting areas of en-echelon faults on the gentle slope, where the uplift magnitude is low and prone to be a structural low, provide the water flow channels, leading to the formation of braided deltas, fan-deltas and lake-floor fans (Fig. 2).

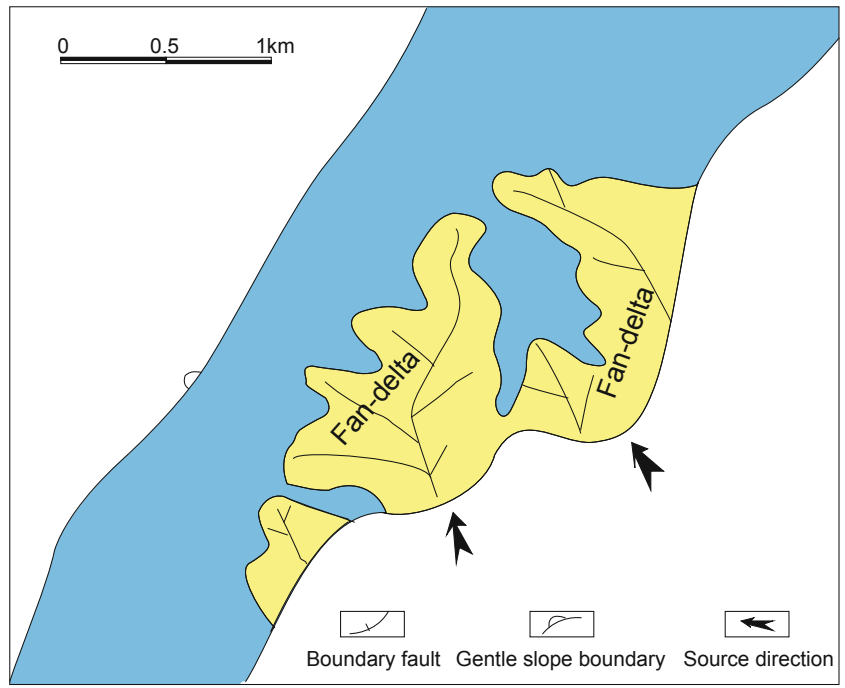

(a) Sediment source charing location at steep slope

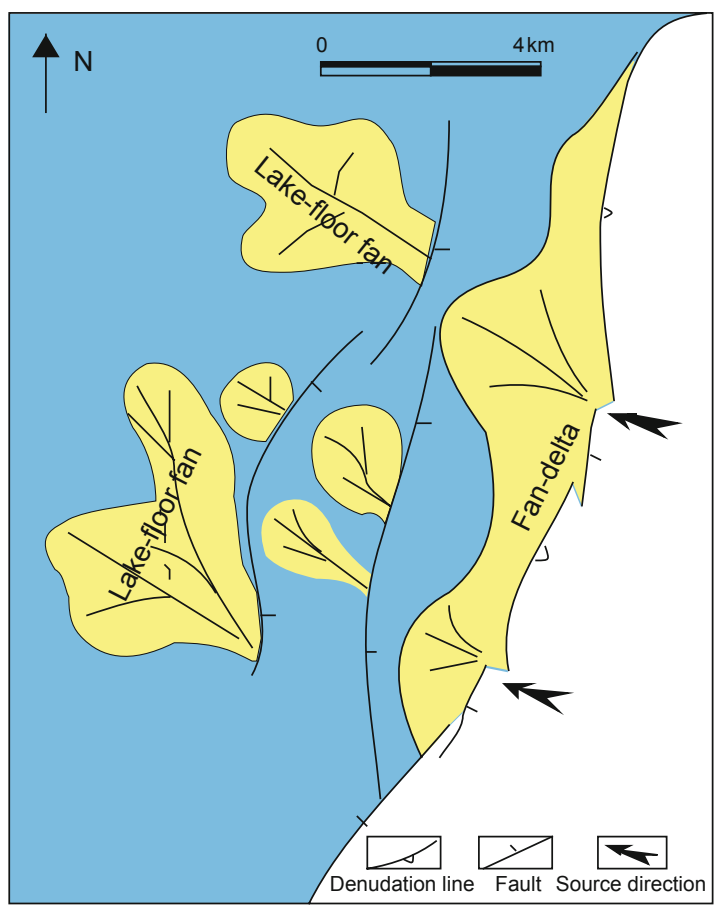

(b) Sediment source charing location at gentle slope

Fig. 2 Relationship of boundary fault style and sediment source charging

\subsection{Type of structural zones controlling depositional systems}

Troughs in faulted depressions are controlled by boundary faults. They are generally characterized by a steep slope on one side, a gentle slope on the other side, and a deep trough in the middle. As a result, sandbodies are deposited in different depositional systems (Fig. 3). On the steep slopes, proximal fan-deltas and sublacustrine fan systems are more likely to develop. On the gentle slopes, distal deltaic systems are dominant. In the deep trough, which is generally narrow (10$20 \mathrm{~km}$ wide), sediments from both sides can reach the center and lead to the development of lake-floor fans. For example, 
on the steep slope of the southern trough in the inverted Bayindulan faulted depression, traction current-dominated fan-deltaic facies were deposited. On the steep slope of the listric fault in the southern trough in the Wuliyasitai faulted depression, owing to the steep terrain, sediments run into the lake along the downthrown side, thus resulting in the development of proximal sublacustrine fans. On the slightly tilted gentle slope of the central trough in the Jiergalangtu faulted depression, braided deltas were developed. On the strongly tilted steep slope of the southern trough in the Wuliyasitai faulted depression, sediments were directly transported to the lake and led to the development of fandeltas.
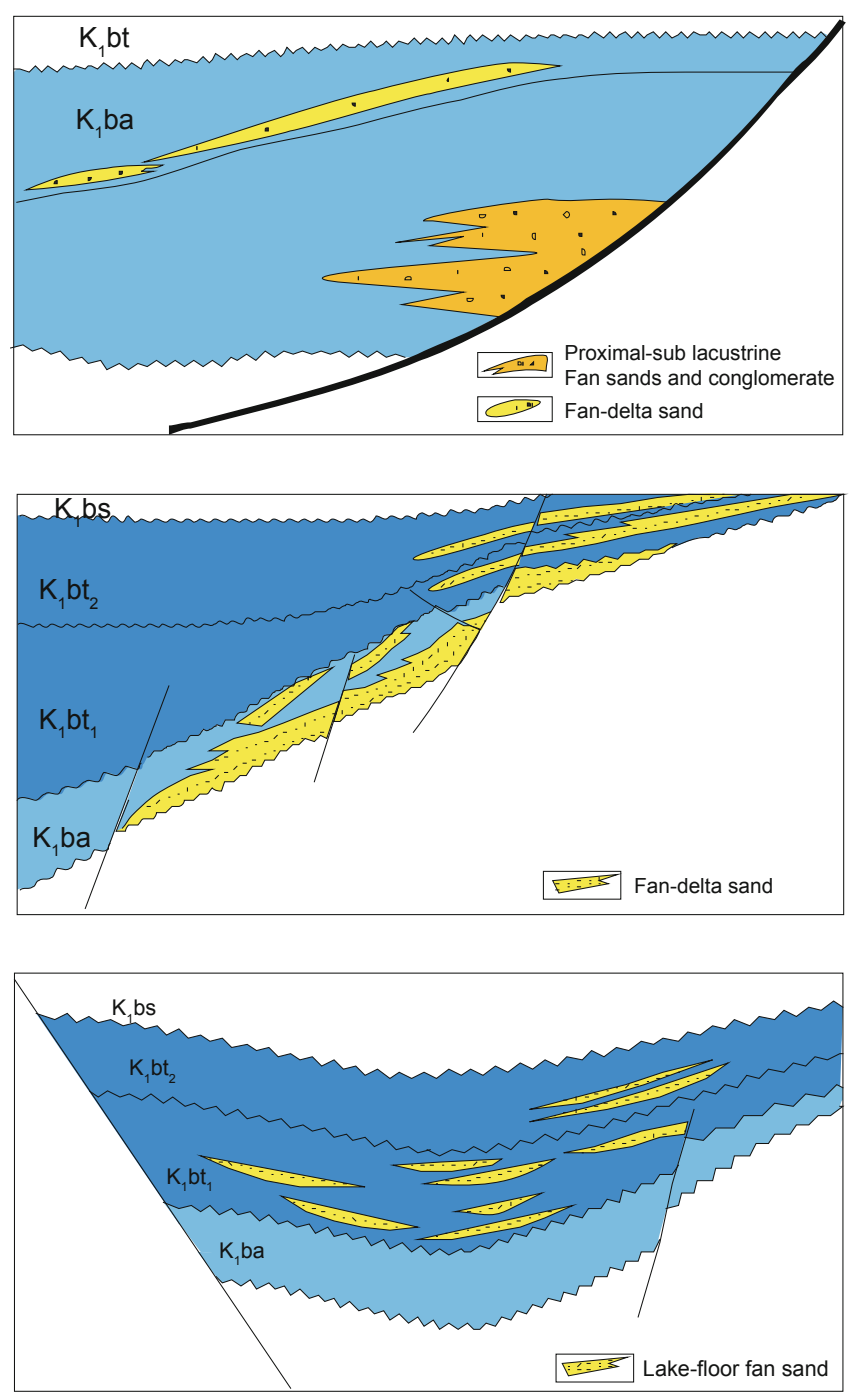

Fig. 3 Sedimentary characteristics of trough areas

\subsection{High-stand systems tract controlling development of high quality sand reservoirs}

In different systems tracts, different genetic types of sandbodies are developed. In faulted basins, the water has a limited area and is shallow during low-stand phases. The sediment supply is sufficient, so that the trough area is dominated by "red and coarse" facies except on the borders. The deposited sandstones are generally poorly-sorted and have poor physical properties. But in the transgressive systems tract phase, the water quickly deepened and enlarged, leading to poor development of sandbodies and the deposition of semi-deep to deep lake dark mudstones, which are the main source rocks. In the high-stand systems tract phase, though the basin continued to subside, the detrital source area played a more important role and the slopes along the basin boundaries became gentle. Therefore, on the steep side proximal sublacustrine fans or fan-deltas are developed, while on the gentle side large-scale braided delta or fan-delta facies are deposited, forming sandbodies with good reservoir properties.

\subsection{Slope break belt controlling depositional facies and distribution of sandbodies}

Different kinds of slope break belts lead to the development of different types of sandbodies and their distribution. The faulted slope break belt near the well Lin-5 in the central trough in the Jiergalangtu faulted depression controlled the development of the braided delta front sandbody which has an updip pinchout (Jiang et al, 2004). The faulted slope break belt near the well Tai-21 in the southern trough in the Wuliyasitai faulted depression controlled the development of lenticular lake-floor fan sandbodies (Yi et al, 2006). The folded slope break belt near the well Tai-17 and the unconformity in the southern trough in the Wuliyasitai faulted depression controlled the development of the fan-delta front sandbody which has an erosional updip pinchout (Du et al, 2004a). The depositional slope break belt near the well Ji-36 in the central trough in the Jiergalangtu faulted depression controlled the development of a lenticular fan-delta front sandbody. The erosional slope break belt near the well Taican- 1 in the southern trough in the Wuliyasitai faulted depression controlled the development of a lake-floor fan sandbody which has an updip pinchout.

\subsection{Microfacies controlling high quality sand reservoirs}

Sandbodies of different origins show different features in the trough area in the faulted Erlian Basin. Fan-deltas are mainly located on steep slopes. They appear fan-shaped or tongue-shaped and have an area of $30-50 \mathrm{~km}^{2}$ in plane view, and look like wedge-shaped or lenticular in section view. Favorable fan-delta front facies are dominated by poorly to moderately sorted sandy conglomerate and conglomeratic sandstone. The best reservoir consists of main channel and distributary channel sands in the delta front. The individual sand layer is $3-8 \mathrm{~m}$ thick and the sandstone has a porosity of $10 \%-20 \%$ and a permeability of $(10-30) \times 10^{-3} \mu \mathrm{m}^{2}$. The braided delta mainly lies on the gentle slope. It appears lobate and has an area of $40-80 \mathrm{~km}^{2}$ in plane view and looks like a prograding broom in section view. Braided river delta fronts also make favorable facies. They are dominated by moderately to well sorted conglomeratic sandstone. The best reservoir consists of distributary channel and mouth bar sands in the delta front. The individual sand layer is 2-5 m thick and the sandstone has a porosity of $15 \%-25 \%$ and a permeability of $(30-60) \times 10^{-3} \mu^{2}$. The proximal sublacustrine fan is mainly 
situated on the steep slope. It appears fan-shaped and has an area of $20-30 \mathrm{~km}^{2}$ in plane view and looks wedge-shaped in section view. Another favorable facies is middle fan, which is dominated by poorly-sorted sandstone and conglomerate. The best reservoir is composed of middle-fan channel facies. The individual sand layer is $5-10 \mathrm{~m}$ thick and the sandstone has a porosity of $8 \%-10 \%$ and permeability of less than $10 \times 10^{-3} \mu \mathrm{m}^{2}$. Lake-floor fans are mainly confined to the trough area. They appear to be lobate or tongue-shaped and have an area of $10-20 \mathrm{~km}^{2}$ in plane view, but appear undulating and filledincised valleys in section view. Favorable facies are inner fan and middle fan, which are dominated by poorly sorted conglomerate and sandstone. The best reservoir is main channel and braided channel facies. The individual sand layer is $5-15 \mathrm{~m}$ thick and the sandstone has a porosity of $15 \%-25 \%$ and permeability of less than $10 \times 10^{-3} \mu \mathrm{m}^{2}$.

\section{Features of hydrocarbon accumulation in troughs in faulted depressions}

\subsection{Preferential hydrocarbon accumulation in trough areas}

Compared with structural highs, troughs are characterized by poor development of structural traps, deeper burial of target zones, poor petrophysical properties of reservoirs, relative dispersion of hydrocarbon migration and relatively small scale accumulations. Nevertheless in troughs highquality hydrocarbon source rocks are interbedded with sheetlike sandbodies (Zhao et al, 2005a), which is favorable for hydrocarbon accumulation over an extensive area. As a result, the high probability for hydrocarbon accumulation in trough areas can be attributed to the following reasons.

Firstly, traps tend to be formed early in troughs. Troughs are not only the main hydrocarbon generation area, but also the place where favorable sandbodies are deposited, leading to frequent interbedding of source rocks and sands (Zhao et al, 2004). Under appropriate conditions, the sandbodies encased within source rocks can easily form lithologic traps. These sandbodies take the advantage of early stage sedimentation and diagenesis, and direct contact with source rocks, so that primary migration can directly result in hydrocarbon accumulation in these lithological traps.

Secondly, hydrocarbon first charges traps in the troughs. Because of sustained subsidence, source rocks in troughs reach the generation threshold at the earliest time, then hydrocarbons first accumulate in sandbody traps in the troughs by means of primary migration, which is characterized by early and long filling time and high filling degree. In contrast, for structural traps, which rely on structures and are always far away from source rocks in both lateral and vertical directions, the hydrocarbons expelled from source rocks accumulate following secondary migration. This process will be much longer, depending on the migrating speed and efficiency, migration system and dynamic conditions. For example, in the central trough in the Jiergalangtu faulted depression, the homogenization temperature data of brine inclusions indicate that the Lin-5 lithological trap was charged earlier than the Ji-46 structural reservoir (Figs. 4 and 5).

Thirdly, reservoirs are widely distributed in troughs. Since hydrocarbons migrate from high potential to low potential zones, the lithological traps still lie in the low potential zone during the hydrocarbon charging time and thus can entrap oil and gas at an early stage. It is possible that they will be transformed into a high potential zone by later structural and depositional evolution. Therefore, hydrocarbon accumulations in lithological traps can be found in the current low potential zone and as well in high potential zones, and in structural highs and structural lows.

Finally, hydrocarbon accumulations can be well preserved in troughs. As we know, numerous structural traps may be destroyed by subsequent structural activities, leading to the dissipation of entrapped hydrocarbons in these traps. However, troughs generally suffer the weakest destruction during tectonic activities, so the previous accumulations can be better preserved. In spite of some alteration, they usually subside or rise or tilt as a whole, causing an adjustment

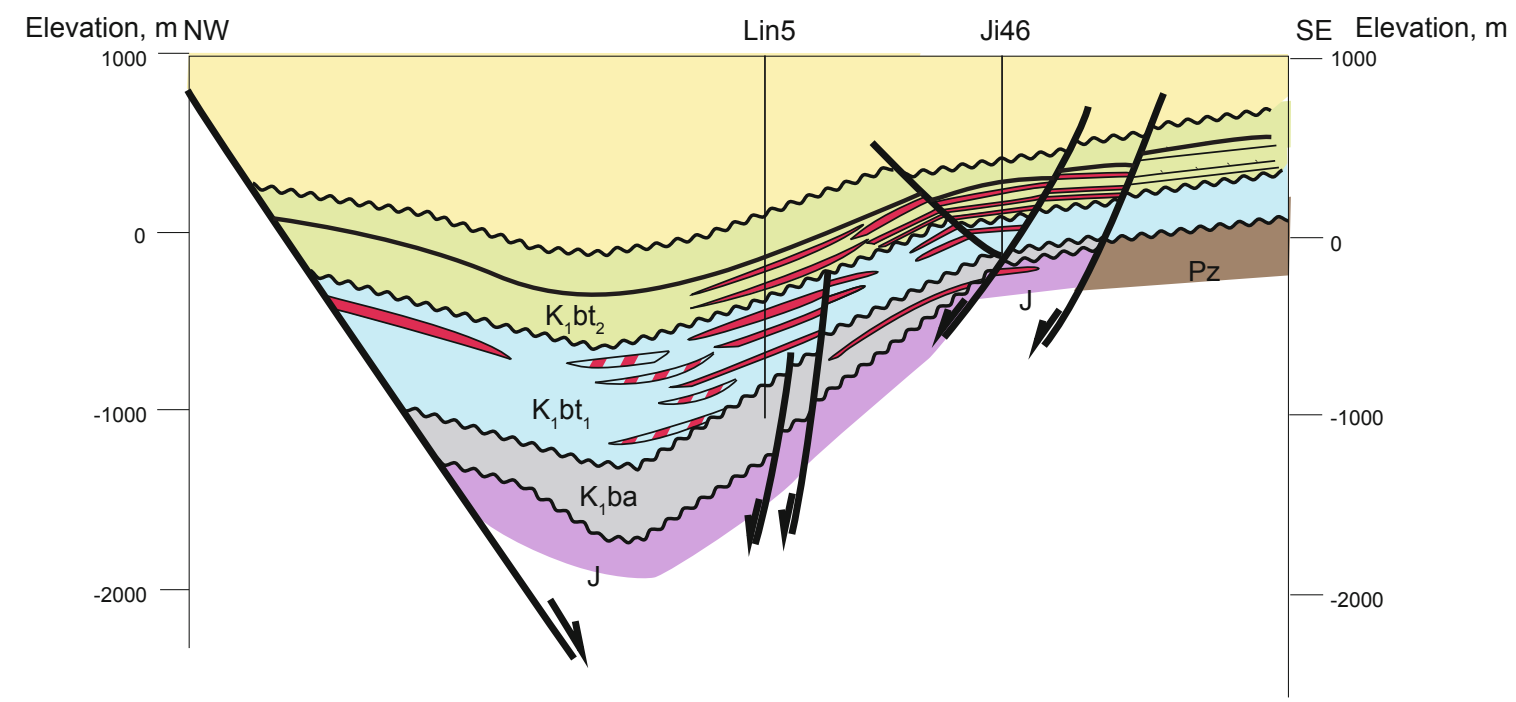

Fig. 4 Lin5-Ji46 reservoir profile in the Jiergalangtu faulted depression 


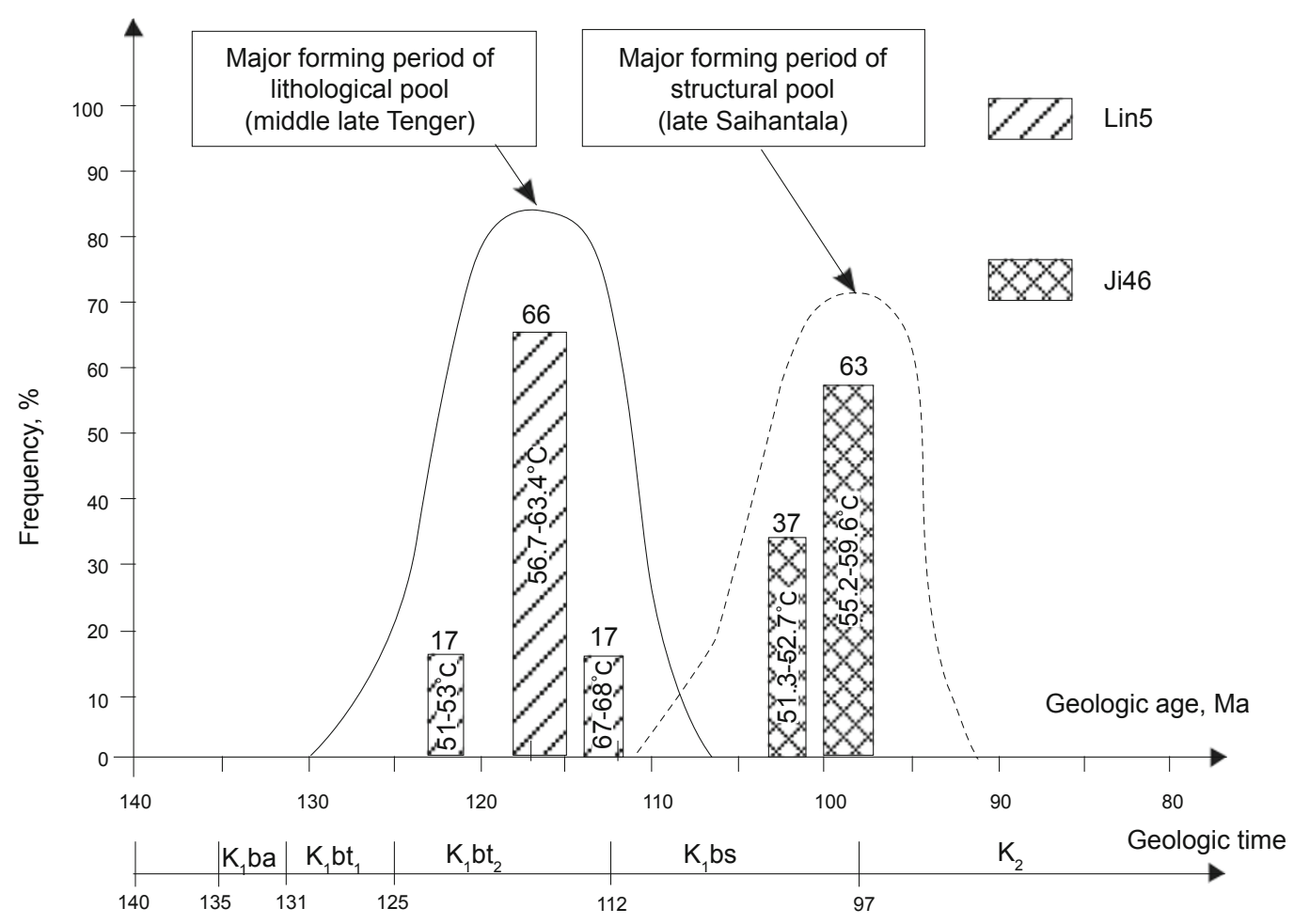

Fig. 5 Homogenization temperature frequency and age distribution of brine inclusions in Lin5 and Ji46 reservoirs

among oil, gas and water. Rarely will the entire accumulation be destroyed.

\subsection{Enrichment of oil in the main trough and three factors controlling the formation of large hydrocarbon accumulations in lithological traps}

"Source-control theory" ( $\mathrm{Hu}, 1982)$ serves as a basic theory in continental hydrocarbon-bearing basins. In continental faulted basins, one faulted depression is a unique source-reservoir unit. However, not only is the inner basin strongly divided, but also each faulted depression is separated into several troughs, where "source-control theory" seems more applicable. For example, the Erlian Basin contains more than 50 faulted depressions, and it is confirmed by drilling that more than 20 faulted depressions contain adequate source rocks, and commercial discoveries have been found in 13 of them. Basin modeling indicates that two thirds of the total resource in the main faulted depression of the Erlian Basin is distributed in the major trough which accounts for one third of the depression area (Table 1). By overlapping the exploration result maps with the hydrocarbon generation and expulsion intensity maps of highly explored depressions, it is clear that the discovered accumulations mostly lie adjacent to the zones of high generation intensity. Few discoveries have been made in areas with the intensity of less than $50 \times 10^{4} \mathrm{t} /$ $\mathrm{km}^{2}$. This finding indicates that migration distances are short in faulted depressions.

In detail, the trough controls the hydrocarbon generation, migration and accumulation in a given faulted depression, which means that hydrocarbons are mostly distributed inside or near the trough. Not all the troughs contain adequate source rocks and only the relatively large ones do. Once the main hydrocarbon-generating trough is found, it is possible to make discoveries in the trough. On the contrary, in the areas away from the main trough, either oil source rocks are insufficient or the oil is of poor quality. Hence, it is difficult to make significant discoveries. Thus, in faulted basins, in general oil is controlled by the faulted depression, but more specifically, it is the main trough that controls the oil. In exploration practice, delineation of the main source kitchen, i.e. the main trough, is the starting point.

The finding that the main troughs are rich in oil does not suggest that there are large accumulations everywhere in the trough. According to the studies of the areas explored by Huabei Oilfield Company, we have found that the generation intensity, the scale of the reservoir and the migrating direction are the three major factors controlling the formation of large hydrocarbon accumulations in lithological traps (Zhao et al, 2008a). The statistical standards are as follows. (1) The hydrocarbon generation intensity should be more than $100 \times 10^{4} \mathrm{t} / \mathrm{km}^{2}$. (2) The scale of the sandbody should be larger than $10 \mathrm{~km}^{2}$. (3) The traps should be located on the main gathering pathways of migration (Table 1). For example, the Baolige discovery with oil in place of $50 \times 10^{6} \mathrm{t}$ in the southern trough of the Bayindulan faulted depression (Fig. 6), the Murige discovery with oil in place of $50 \times 10^{6} \mathrm{t}$ in the southern trough of the Wuliyasitai faulted depression, and the Liuxi trough discovery with oil in place of $50 \times 10^{6} \mathrm{t}$ in the Raoyang faulted depression are all located in the areas where all the three main factors are favorable. In contrast, few discoveries have been made in the areas where one or more of the three factors are not adequate. 
Table 1 Features of main troughs and major factors controlling hydrocarbon enrichment in continental faulted depressions

\begin{tabular}{|c|c|c|c|c|c|c|c|}
\hline Main trough & $\begin{array}{l}\text { Percentage } \\
\text { of main } \\
\text { trough area }\end{array}$ & $\begin{array}{l}\text { Percentage of } \\
\text { total hydrocarbon } \\
\text { resources } \\
\text { in main trough }\end{array}$ & $\begin{array}{l}\text { Discovered } \\
\text { major oil } \\
\text { accumulations }\end{array}$ & $\begin{array}{l}\text { Oil in } \\
\text { place, } \\
10000 t\end{array}$ & $\begin{array}{l}\text { Hydrocarbon } \\
\text { generation } \\
\text { intensity, } \\
10000 \mathrm{t} / \mathrm{km}^{2}\end{array}$ & $\begin{array}{l}\text { Reservoir } \\
\text { features }\end{array}$ & $\begin{array}{l}\text { Hydrocarbon } \\
\text { accumulation } \\
\text { pattern }\end{array}$ \\
\hline \multirow{2}{*}{$\begin{array}{l}\text { Southern trough } \\
\text { of Bayindulan } \\
\text { Depression }\end{array}$} & \multirow{2}{*}{$41.7 \%$} & \multirow{2}{*}{$63.2 \%$} & Ва 19, Ва 38 & $>3000$ & $100-600$ & $\begin{array}{l}\text { Fan-delta } \\
\text { front sand, } \\
\text { area: } 10 \mathrm{~km}^{2}\end{array}$ & $\begin{array}{l}\text { In situ sourced and reservoired, } \\
\text { main catchment area of migrating } \\
\text { oil and gas, sands and faults } \\
\text { acting as migration pathways }\end{array}$ \\
\hline & & & $\mathrm{Ba} 10, \mathrm{Ba} 5$ & $>2000$ & $100-400$ & $\begin{array}{l}\text { Fan-delta } \\
\text { front sand, } \\
\text { area: } 15 \mathrm{~km}^{2}\end{array}$ & $\begin{array}{l}\text { In situ sourced and reservoired, } \\
\text { main catchment area of migrating } \\
\text { oil and gas, sands and faults } \\
\text { acting as migration pathways }\end{array}$ \\
\hline $\begin{array}{l}\text { Baorao trough } \\
\text { of Jiergalangtu } \\
\text { Depression }\end{array}$ & $37.9 \%$ & $62.3 \%$ & $\begin{array}{c}\operatorname{Lin} 4, \operatorname{Lin} 5, \\
\operatorname{Lin} 7, \operatorname{Jin} 45\end{array}$ & $>4000$ & $100-1000$ & $\begin{array}{l}\text { Braided delta } \\
\text { front sand, } \\
\text { area: } 18 \mathrm{~km}^{2}\end{array}$ & $\begin{array}{l}\text { In situ sourced and reservoired, } \\
\text { main catchment area of migrating } \\
\text { oil and gas, sands and faults } \\
\text { acting as migration pathways }\end{array}$ \\
\hline $\begin{array}{l}\text { Southern trough } \\
\text { of Wuliyasitai } \\
\text { Depression }\end{array}$ & $42.8 \%$ & $55.4 \%$ & Tai 17, Tai 41 & $>5000$ & $100-900$ & $\begin{array}{l}\text { Lake-floor } \\
\text { fan, fan-delta } \\
\text { front sand, } \\
\text { area: } 22 \mathrm{~km}^{2}\end{array}$ & $\begin{array}{l}\text { In situ sourced and reservoired, } \\
\text { main catchment area of migrating } \\
\text { oil and gas, sands, faults and } \\
\text { unconformities acting as } \\
\text { migration pathways }\end{array}$ \\
\hline $\begin{array}{l}\text { Liuxi, Maxi, Hejian } \\
\text { and Renxi Troughs } \\
\text { of Raoyang } \\
\text { Depression }\end{array}$ & $42.9 \%$ & $85.1 \%$ & $\mathrm{Lu} 43, \mathrm{Lu} 44$ & $>5000$ & $150-1300$ & $\begin{array}{l}\text { Braided delta } \\
\text { front sand, } \\
\text { area: } 26 \mathrm{~km}^{2}\end{array}$ & $\begin{array}{l}\text { In situ sourced and reservoired, } \\
\text { main catchment area of migrating } \\
\text { oil and gas, sands and faults } \\
\text { acting as migration pathways }\end{array}$ \\
\hline
\end{tabular}

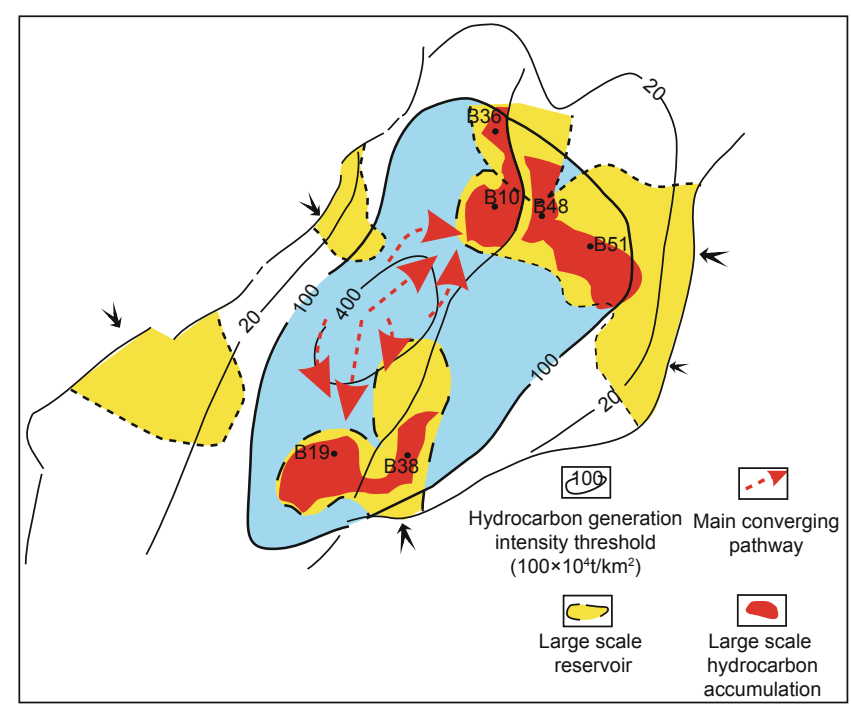

Fig. 6 Key-factor enrichment in the southern trough of the Bayindulan Depression

\subsection{Co-existence and complementing of structural and lithological accumulations}

In faulted depressions, structural accumulations and lithological accumulations form in the same or similar regional structural-depositional setting and hydrocarbon source conditions, which means that they can co-exist with each other. The co-existence is characterized by the following features. (1) Structural accumulations and lithological accumulations can be found together in hydrocarbon-rich faulted depressions, and they are mostly confined to the favorable structural region surrounding the hydrocarbon generation trough. For example, the Raoyang Depression, the richest one in the Jizhong Depression, contains the largest share of oil reserves accumulated in structural traps. It also hosts the most abundant lithological accumulations. (2) Structural accumulations and lithological accumulations basically occur in the same stratigraphic interval. For example, in the Liuxi-Dawangzhuang area, $\mathrm{Es}_{3}$ and $\mathrm{Ed}$ are the major oil-bearing intervals, which contain the bulk of the discovered oil in both structural and lithological traps (Table 2).

Table 2 Distribution of oil in place in different reservoirs and trap types in the Raoyang Depression

\begin{tabular}{cccc}
\hline Interval & $\begin{array}{c}\text { Structural } \\
\text { traps, 10 }\end{array}$ & $\begin{array}{c}\text { Stratigraphic } \\
\text { traps, 10 }\end{array}$ & $\begin{array}{c}\text { Oil in place ratio of } \\
\text { structural traps to } \\
\text { stratigraphic traps }\end{array}$ \\
\hline $\mathrm{Ed}$ & 3832 & 3145 & $1: 0.82$ \\
$\mathrm{Es}_{1}$ & 1928 & 1325 & $1: 0.69$ \\
$\mathrm{Es}_{2}$ & 873 & 913 & $1: 1.05$ \\
$\mathrm{Es}_{3}$ & 1824 & 2717 & $1: 1.49$ \\
\hline
\end{tabular}

The differences between the formation of structural accumulations and that of lithological accumulations 
commonly result in their complementing each other (Du et al, 2004b), which is characterized by the following features. (1) Structural accumulations concentrate on the crests of the structural highs characterized by strong structural activities, multiple faults and well-developed structural traps, while lithological accumulations mainly occur in the troughs characterized by weak structural activities, which also include the middle-lower parts of the structural highs and slope (especially the slope break belt). Thus, structural accumulations and lithological accumulations complement each other in terms of development at different parts of the structures and different phases of structural development. (2) The area with a high sand ratio of up to $60 \%$ or more tends to favor the development of structural accumulations. "Toothbrush-like" fault block pools are usually formed if faults are well developed. The area where the sand ratio is less than $30 \%$ tends to favor the development of lithological accumulations. The structural accumulations and lithological accumulations complement each other by development in different sedimentary facies of the same depositional system. (3) Structural accumulations are normally featured by normal or low pressure systems where the pressure coefficients are mostly less than 1.0, but lithological accumulations have high pressure systems where the pressure coefficients are usually greater than 1.0. Thus, they complement each other by development at different potential zones of the same petroleum system.

By statistical analyses and modeling of hydrocarbon accumulation dynamics of the discovered fields in the highlyexplored faulted depressions in the Jizhong Depression and the Erlian Basin, we know that in the major troughs, oil in place or oil resources entrapped in structural traps have a negative relationship with those in stratigraphic traps. This relationship is affected by the structural development degree, and their relative ratio lies in the range of 1:0.7 to 1:1.4 (Table 3 ). When structural traps are well developed and net sand ratio is high, oil tends to accumulate in structural traps. In contrast when structural traps are less well developed and the net sand ratio is low, oil tends to accumulate in lithological traps.

\section{Significance in petroleum exploration}

The key elements of the new guidelines for hydrocarbon accumulation and distribution in trough areas in faulted depressions are:

(1) "Sand distribution is controlled by multiple factors",

(2) "lithological accumulations are more likely to form in trough areas",

(3) "three factors control the formation of large lithological hydrocarbon accumulations in trough areas", and

(4) "structural and lithological accumulations not only coexist but also complement each other".

These new principles are largely different from the "second order structural zone" concept and they have made a significant contribution to the overall evaluation of the hydrocarbon prospects of trough areas. The principles have brought new breakthroughs in the exploration of oil and gas in the trough areas in the Jizhong Depression and the Erlian
Basin (Zhao et al, 2009).

Table 3 Distribution of oil in place in different reservoirs and trap types in different troughs

\begin{tabular}{|c|c|c|c|c|}
\hline Trough & $\begin{array}{l}\text { Main } \\
\text { Reservoir } \\
\text { interval }\end{array}$ & $\begin{array}{l}\text { Structural } \\
\text { traps, } 10^{4} \mathrm{t}\end{array}$ & $\begin{array}{l}\text { Stratigraphic } \\
\text { traps, } 10^{4} \mathrm{t}\end{array}$ & $\begin{array}{l}\text { Oil in place ratio } \\
\text { of structural traps } \\
\text { to stratigraphic } \\
\text { traps }\end{array}$ \\
\hline $\begin{array}{c}\text { Dawangzhuang-Liuxi } \\
\text { Trough in Raoyang } \\
\text { Depression }\end{array}$ & Ed, Es & 3902 & 5275 & $1: 1.35$ \\
\hline $\begin{array}{c}\text { Hejian Trough in } \\
\text { Raoyang Depression }\end{array}$ & Ed, Es & 1268 & 1353 & $1: 1.07$ \\
\hline $\begin{array}{c}\text { Renxi Trough in } \\
\text { Raoyang Depression }\end{array}$ & Ed, Es & 1485 & 1127 & $1: 0.76$ \\
\hline $\begin{array}{c}\text { Southern trough of } \\
\text { Bayindulan } \\
\text { Depression }\end{array}$ & $\begin{array}{l}\text { A'ershan } \\
\text { Formation }\end{array}$ & 2252 & 1490 & $1: 0.66$ \\
\hline $\begin{array}{c}\text { Baorao Trough of } \\
\text { Jiergalangtu } \\
\text { Depression }\end{array}$ & $\begin{array}{c}\text { Tenger } \\
\text { Formation }\end{array}$ & 1225 & 1149 & $1: 0.94$ \\
\hline $\begin{array}{c}\text { Southern trough } \\
\text { of Wuliyasitai } \\
\text { Depression }\end{array}$ & $\begin{array}{c}\text { Tenger } \\
\text { Formation, } \\
\text { A'ershan } \\
\text { Formation }\end{array}$ & 1293 & 994 & $1: 0.77$ \\
\hline
\end{tabular}

\subsection{Broadening the exploration domain}

By improving the theory of hydrocarbon accumulation in complex structural belts, these new principles elevate the exploration value of trough areas and broaden the exploration domain from the previous "defining the depression first and then exploring the structural highs" to "defining the trough and exploring the trough". The exploration domain has been extended from structural traps to lithological traps as well. These principles have laid the foundation for the overall evaluation of the entire depression and exploration for oil and gas throughout the depression.

\subsection{Accomplishment of six extensions in exploration}

The six extensions in exploration include extension from structural traps to lithological traps, from positive structural belts to negative structural zones, from structural highs to slopes of the structural belts, from structural belts to structure-facies belts, from depression margins to troughs, and from single trap type to multiple trap types. Meanwhile, the exploration concepts have changed as well, and more attention has been paid to lithological and stratigraphic plays.

\subsection{Establishment of a new exploration methodology}

In the past, the major exploration method in faulted basins was "defining the depression first and then exploring the structural high". The exploration procedure was "defining the depression-choosing the structural belt-looking for anticlinedrilling the crest", which is suitable for structural traps. Based on the new principles of hydrocarbon accumulation 
in troughs, however, we can reinforce the exploration for lithological accumulations and search for those related to structure-facies belts. In faulted depressions with well developed structures, we should emphasize exploration for structural accumulations, while in those with less well developed structures, we should strengthen the exploration for lithological accumulations. The corresponding procedure is "defining the depression-confirming the setting-establishing the model-describing sandbodies-evaluating thoroughlyrolling exploration".

(1) Defining the depression. Guided by the complementary distribution between structural accumulations and lithological accumulations, we start basin modeling and comparison analysis of discovered reserves with predicted resources. As a result, the exploration potential of the trough areas is known and oil-rich troughs are prioritized for further exploration.

(2) Confirming the setting. It means to focus on the oilrich troughs. Under the circumstances of lack of anticlines, fault noses and fault blocks, the investigation should concentrate on the structural and depositional setting. We seek nose belts, inverted structural belts, slope break belts, onlapping belts and erosional belts, discuss the effect of structure on sandbodies, and find out the favorable structurefacies belts in a chrono-stratigraphic framework.

(3) Constructing model. It involves analyzing the relationship between structure and sandbodies, studying conditions for predominant hydrocarbon migration and accumulation, and the factors for hydrocarbon enrichment. The exploration intervals are prioritized and the favorable accumulation models are set up.

(4) Describing sandbodies. It refers to forecasting the distribution of sandbodies by seismic technologies, especially depicting the geometry of isolated sandbodies in order to delineate stratigraphic and lithological traps.

(5) Evaluating thoroughly. It involves integrating geological data and various factors for hydrocarbon accumulation to assess all the structure-facies belts and set up the accumulation models. All the stratigraphic and lithological traps should be evaluated and prioritized for selection of exploration targets. In highly explored areas, the abundant data should be fully utilized and old wells should be rechecked. The discovery of the clues indicating hydrocarbon accumulation is vital to trap evaluation and selection of exploration targets.

(6) Rolling exploration. Considering the trap types are fairly complex, there exist numerous uncertain factors, and the exploration risk is quite high in trough areas. It would be better to perform rolling assessment and rolling exploration, and follow a flexible exploration program. The most favorable area should be drilled first and then a new round of assessment should be carried out according to the drilling results. After that, drilling can be expanded and such a procedure can be repeated as long as new discoveries are being made. In a rolling exploration program, the exploration can be adjusted according to the new drilling results and the drilling success ratio can be maintained to the highest degree so that the exploration in the risky tough areas can be sustained

\subsection{Establishment of new accumulation models in troughs}

It is really difficult to form complex oil accumulations in troughs due to lack of positive structural belts. However, various accumulations can be formed in troughs and they are dominated by lithological accumulations (Table 1). There exist seven models for the hydrocarbon accumulation in lithological traps (Wang et al, 2008; Zhao et al, 2008a; 2008b; 2008c).

(1) Fan-delta front on inverted steep slopes

The south trough of the Bayindulan Depression in the Erlian Basin is taken as an example. The earlier formed trough was inverted and the depocenter was shifted to the newly formed trough. At the flank of the inverted belt, the fan-delta front sandbodies pinch out updip, leading to the development of self-sourced and self-reservoired lithological accumulations. Based on this model, the Baolige oil field with oil in place of $50 \times 10^{6}$ t has been found.

(2) Delta or fan-delta fronts and lake-floor fans on gentle slope break belts

The southern trough of the Wuliyasitai Depression is taken as an example. Multiple slope breaks are developed on the gentle slope so that delta or fan-delta sands and lakefloor fan sandbodies were deposited. They are in contact with source rock downdip and pinch out updip. As a result, selfsourced and self-reservoired lithological accumulations were formed. The Wuliyasitai Murige oil field with $50 \times 10^{6}$ t oil in place was found using this model.

(3) Channel sands along toes of fault scarps

The trough along the downthrown wall of the Dawangzhuang eastern fault in the Raoyang Depression is taken as an example. The long-lasting active Dawangzhuang eastern fault cut deep into source rocks, leading to the formation of an inherited negative structure zone at the downthrown wall. The sandbodies in the Dongying Formation are distributed in a zoned pattern along the foot of the fault. As a result, the updip pinchout lithological traps were charged by oils generated from the underlying older source rocks. Using this model, the Lu 70 lithological accumulation with oil in place of $10 \times 10^{6} \mathrm{t}$ has been found and the oil is reservoired in the channel sands of the Dongying Formation.

(4) Laterally accreted delta fronts on faulted terraces

In the Liuxi Trough in the Raoyang Depression, source rocks and encased lobate delta front sandbodies were deposited on the faulted monoclinal steep terrace. The sandbodies pinch out laterally and are sealed by faults updip so that self-sourced and self-reservoired lithological accumulations were formed. With this model, the Liuxi accumulation with oil in place of $50 \times 10^{6}$ thas been found.

(5) Onlapping on an eroded buried hill

The Diannan Trough in the Raoyang Depression is taken as an example. Associated with the Yanling buried hill and its paleo-topography, several types of sandbodies of lake shore zone and shallow lake origins and delta front sands were deposited on the slopes surrounding the buried high. 
Within the sedimentary successions, several unconformities were developed. As a result, self-sourced and self-reservoired lithological accumulations were formed. With this model, we have found discoveries with oil in place of $30 \times 10^{6} \mathrm{t}$.

(6) Oil reservoired and sealed within a buried hill

In the Renxi Trough in the Raoyang Depression, the Changyangdian buried hill was found. Within the hill, the reservoir interval is the Wumishan Formation which is sealed updip by non-reservoir rocks of the Cambrian and Qingbaikou Systems through faulting. Thus, oil is reservoired and sealed within the buried hill. Using this model, we have found the productive Chang 3 buried hill oil accumulation.

(7) Intra-buried-hill on terraced substratum

Along the faulted terrace belt in the western Saidong Trough of the Saihantala Depression in the Erlian Basin, Carboniferous carbonates are overlain by the Mesozoic igneous rocks. The carbonate reservoirs are connected with the source rocks within the trough by terraced faults. As a result, intra-buried-hill accumulations on terraced substratum were formed. They are characterized by oil accumulation in reservoirs within the buried hill from oil derived from laterally distant source rocks. Based on this model, we have discovered productive fields in Carboniferous carbonate reservoirs in the buried hills in the Erlian Basin for the first time. Their volumes of oil in place amount to tens of million tonnes.

\section{Conclusions}

(1) In faulted basins, oil accumulation is controlled by the faulted depression in general, but in particular it is controlled by the main trough within the depression.

(2) Oil accumulation in the trough area is characterized by short-range migration, early hydrocarbon charging and good preservation conditions. The areas where the hydrocarbon generation intensity is more than $100 \times 10^{4} \mathrm{t} /$ $\mathrm{km}^{2}$, the sandbodies are larger than $10 \mathrm{~km}^{2}$ in size, and the traps are located on the main gathering migration pathways, tending to be the main oil-rich zones. Depending upon the geological elements for hydrocarbon accumulation, the oil in place in structural accumulations has a negative relationship with that in lithological accumulations, but the oil in place ratio of structural accumulations to lithological accumulations generally lies in the range of 1:0.7 to $1: 1.4$.

(3) In troughs complex oil accumulations similar to those in structural zones are unlikely to form. However, oil can accumulate in stratigraphic and lithological traps in fan-delta front sands on inverted belts, delta or fan-delta fronts and lake-floor fan sands on gentle slope break belts, channel sands along toes of fault scarps and in buried hill reservoirs. Such oil accumulations can be of significant scale to form oil rich zones within troughs.

(4) The methodology of "defining the depressionconfirming the setting-establishing the model-describing sandbody-evaluating thoroughly-rolling exploration" and "defining the trough and exploring the trough" make it possible to explore for oil and gas in troughs effectively.

\section{References}

Du J H, Yi S W and Wang Q. In-depth study and exploration practice of subtle oil reservoirs of Huabei Oilfield. China Petroleum Exploration. 2003. 8(1): 1-10 (in Chinese)

Du J H, Yi S W, Lei H Y, et al. Formation conditions for lithologic and stratigraphic oil reservoirs and oil and gas distribution in the Erlian Basin. China Petroleum Exploration. 2004a. 9(3): 1-5 (in Chinese)

Du J H, Yi S W, Lu X J, et al. Oil and gas distribution of an oilenriched depression characterized by "reciprocity". China Petroleum Exploration. 2004b. 9(1): 17-22 (in Chinese)

$\mathrm{Hu} \mathrm{C}$ Y. Source bed controls hydrocarbon habitat in continental basins, East China. Acta Petrolei Sinica. 1982. 3(2): 9-14 (in Chinese)

$\mathrm{Hu} \mathrm{J}$ Y and Niu J Y. The further deepening of oil-gas accumulation theory and exploration practice in the Bohai Bay Basin. Acta Petrolei Sinica. 2001. 22(1): 1-5 (in Chinese)

Jiang S Q, Si J W, Zhao A J, et al. Exploration of lithologic oil reservoirs in the Jiergalangtu Depression of the Erlian Basin. China Petroleum Exploration. 2004. 9(3): 46-53 (in Chinese)

Jin F M, Zhang R F, Tian J Z, et al. Exploration of lithologic oil reservoirs in the Liuxi Es 3 section in the Raoyang Sag of the Jizhong Depression. China Petroleum Exploration. 2004a. 9(3): 62-66 (in Chinese)

Jin F M, Zhang R F, Yang C H, et al. Exploration of lithologic oil reservoirs in the downthrown block in the east Dawangzhuang fault in the Raoyang Sag of the Jizhong Depression. China Petroleum Exploration. 2004b. 9(3): 58-61 (in Chinese)

Jin F M, Zhao X Z, Wang Q, et al. Formation and exploration of stratigraphic and lithologic reservoirs in the Raoyang Sag. Monographs of new hydrocarbon exploration fields and technologies of China hydrocarbon forum (Word Petroleum Industry). 2008. 97103 (in Chinese)

Li D S. Basic characteristics of oil and gas basins in China. Acta Geoscientica Sinica. 1994. (3-4): 159-166 (in Chinese)

Liu Z, Zhao Z Z, Zhao Y, et al. Predominant characteristics of the formation and distribution of lithologic reservoirs in petroliferous basins. Acta Petrolei Sinica. 2006. 27(1): 17-23 (in Chinese)

Wang Q, Zhao X Z, Jin F M, et al. Typical reservoir forming patterns in sags in fault depressions of terrestrial basins - a case study of the Jizhong Depression and the Erlian Basin. China Petroleum Exploration. 2008. 13(2): 9-12 (in Chinese)

Yi S W, Wang Y J and Qian Z. Formation pattern and distribution features of hydrocarbon reservoirs in the Wuliyasitai Sag of the Erlian Basin. Acta Petrolei Sinica. 2006. 27(3): 27-31 (in Chinese)

Zhao W Z, Zhang G Y and Wang H J. New achievements of petroleum geology theory and its significance for expanding the oil and gas exploration field. Acta Petrolei Sinica. 2005a. 26(1): 1-12 (in Chinese)

Zhao W Z, Zou C N, Wang Z C, et al. The intension and signification of "sag-wide oil-bearing theory" in hydrocarbon-rich depressions of terrestrial origin. Petroleum Exploration and Development. 2004. 31(2): 5-13 (in Chinese)

Zhao X Z and Jin F M. Oil Accumulation Theory in Sags in Fault Depressions of Terrestrial Basins and Its Application-A Case Study of the Jizhong Depression and the Erlian Basin. Beijing: Science Press. 2009 (in Chinese)

Zhao X Z, Jin F M, Liu Z, et al. "Multi-factor controlling, four-factor entrapping and key-factor enrichment" of stratigraphic-lithologic reservoirs and exploration practice in the Erlian Basin (I) - "Multifactor controlling" mechanism. Lithologic Reservoirs. 2007a. 19(2): 9-15 (in Chinese)

Zhao X Z, Jin F M, Wang Q, et al. Oil and gas reservoir formation and 
distribution in sags of fault depressions in the Huabei exploration area. China Petroleum Exploration. 2008a. 13(2): 1-8 (in Chinese)

Zhao X Z, Jin F M, Wang Y Q, et al. Buried-hill reservoir-forming mode of "old reservoir-old sealing formation" in the Changyangdian area of the Jizhong Depression. Acta Petrolei Sinica. 2008b. 29(4): 489493 (in Chinese)

Zhao X Z, Jin F M, Zhao Z G, et al. Discovery and geologic characteristics of Carboniferous basement carbonate reservoirs in the Erlian Basin. Marine Origin Petroleum Geology. 2008c. 13(4):
12-18 (in Chinese)

Zhao X Z, Lu X J and Wang Q. Discoveries and their implications for stratigraphic-lithologic reservoir exploration of the Huabei Oilfield. Oil \& Gas Geology. 2007b. 28(5): 597-604 (in Chinese)

Zhao Z Z, Du J H, Niu J Y, et al. Exploration situations and prospects in PetroChina blocks, Bohai Bay Basin. China Petroleum Exploration. 2005b. 10(3): 1-7 (in Chinese)

(Edited by Hao Jie) 